\title{
Assessment of Genetic Diversity in Nepalese Populations of Swertia chirayita (Roxb. Ex Fleming) H. Karst Using RAPD-PCR Technique
}

\author{
J. K. Chhipi Shrestha ${ }^{1,2}$, T. Bhattarai ${ }^{2}$, J. Sijapati ${ }^{1}$, N. Rana ${ }^{1}$, J. Maharjan ${ }^{1}$, D. S. Rawal ${ }^{1}$, \\ B. B. Raskoti ${ }^{3}$, S. Shrestha ${ }^{*}$ \\ ${ }^{1}$ Molecular Biotechnology Research Unit, Nepal Academy of Science and Technology, Lalitpur, Nepal; ${ }^{2}$ Central Department of Bio- \\ technology, Tribhuvan University, Kathmandu, Nepal; ${ }^{3}$ Institute of Botany, Chinese Academy of Sciences (CAS), Beijing, China. \\ Email: *sangita7@hotmail.com
}

Received June $2^{\text {nd }}, 2013$; revised July $2^{\text {nd }}, 2013$; accepted July $19^{\text {th }}, 2013$

Copyright (C) 2013 J. K. Chhipi Shrestha et al. This is an open access article distributed under the Creative Commons Attribution License, which permits unrestricted use, distribution, and reproduction in any medium, provided the original work is properly cited.

\begin{abstract}
Owing to the high demand, Swertia chirayita populations in the wild are being depleted beyond its regeneration capacity. S. chirayita is one of the most valuable medicinal plants of Nepal in trade. Present Molecular investigation was undertaken to understand the level of genetic diversity in five S. chirayita populations of Nepal using Polymerase Chain Reaction (PCR)-based Random amplified polymorphic DNA (RAPD) technique. Thirty four accessions of S. chirayita along with six outlier accessions were analyzed using 26 arbitrary primers. Of the total 285 amplified bands scored for $S$. chirayita, 263 bands (92.28\%) were polymorphic. Two major clusters were revealed in the phenogram generated from cluster analysis using NTSYS-PC software (version 2.21i) for the geographic populations under study. Principal Coordinate Analysis further substantiated the results of the phenograms. Swertia chirayita populations from Sankhuwasabha and Terathum were found to be genetically closest $(68 \%$, similar) whilst Nagarjun and Terathum were found to be most distant (33\%, similar). The high genetic polymorphism reflected in S. chirayita populations indicates the good survival potentiality and adaptability in changing environmental scenario. The results thus produced might be helpful to plant breeders for elite cultivar development. The RAPD-PCR technique is found to be the rapid and effective tool for genetic diversity assessment in S. chirayita populations and generated insights for the formulation of conservation strategy of this vulnerable species together with its phytochemical distinctiveness.
\end{abstract}

Keywords: PCR; DNA Fingerprinting; Molecular Marker; Genetic Diversity; Polymorphism

\section{Introduction}

Nepal is very rich in medicinal plants and their associated traditional knowledge. Over 1950 medicinal plants have so far been reported [1]. Medicinal plants of Nepal are increasingly depleting and threats to these high value resources are from land fragmentation, degradation, overexploitation as well as prevailing climate change. S. chirayita has been listed as one of the top priority medicinal plants of Nepal as well as of Asia [2].

Swertia, member genus of the family Gentianaceae is widely distributed globally and is represented by over 135 species distributed in temperate areas of Asia, Africa, Europe, North America and Madagascar [3,4]. Owing to diverse physiographic zones, climatic contrasts and alti-

\footnotetext{
*Corresponding author.
}

tudinal gradients, Nepal possesses a rich diversity of Swertia species and boasts thirty species distributed from east to west and from tropical to alpine zones ranging from $600 \mathrm{~m}$ to $5600 \mathrm{~m}$ asl $[5,6]$.

Swertia chirayita (Roxb. Ex Fleming) H. Karst, a legendary medicinal plant species of Nepal is reported to be distributed in 54 districts of Nepal [7]. Due to its highly potent and superior medicinal properties, it is highly demanded in national and international markets and plays a dominant role in trade. Along with S. chirayita, eight other allied species having medicinal properties are also traded viz. S. angustifolia Buch.-Ham. Ex D. Don, S. ciliata (D. Don ex G. Don) B. L. Burtt, S. dilatata C. B. Clarke, S. multicaulis D. Don, S. racemosa (Griseb) C. B. Clark, S. tetragona Edgew, S. alata (Royle ex D. Don) C. B. Clarke and S. nervosa (G. Don) C. B. Clarke [8,9]. 
Nepal is reported to trade more than $45 \%$ of the world's total volume of $S$. chirayita [10] of which only $1 \%$ is being used locally and the rest is being exported to India, China, Malaysia, Singapore, Germany, Italy, France, Switzerland, Sri Lanka, Bangladesh, Pakistan and USA to fulfill the demand of various medicinal plant based industries [11].

Swertia chirayita is a multifaceted medicinal plant containing diverse bioactive chemical compounds and properties. Early studies documented the presence of several chemical compounds in S. chirayita such as chiratinin, gentianine, amarogentin, amaroswerin, and several flavonoids, xanthones, terpenoids, iridoids and secoiridoid glycosides [12-14]. These bioactive compounds and their derivatives are reported to have anti inflammatory, antidiabetic, antihepatotoxic, antileishmanial, anticarcinogenic, antiviral and antihelmithic properties [15-18].

Due to versatile medicinal properties of $S$. chirayita, it is suffering from indiscriminate and unscientific harvesting from its natural habitats to fulfill national and international demands [2]. This has rendered $S$. chirayita to be listed as critically endangered in India and vulnerable in Nepal by CITES and IUCN [19]. Therefore, an urgent need has been felt to conserve the existing diversity of this valuable germ plasm of Nepal and protect its habitats from further destruction, for its long term and sustainable utilization. As the survival index of a species is greatly determined by the existing polymorphisms and gene flow between populations, assessing genetic diversity and natural distribution pattern are considered vital for formulating conservation strategies of vulnerable species such as S. chirayita [20]. For a species to survive against environmental pressures, the availability of a pool of genetic diversity is an essential prerequisite. Extinction would appear inevitable in its absence [21]. Phytochemical distinctiveness is also linked to the genetic diversity [22].

An understanding of the breeding system (self or cross) is fundamental to any genetic improvement program. Regarding S. chirayita, few works have so far been carried out on cytology, genetics and reproductive biology. It was reported to be a cross pollinated species [23] without any field experiment. Recent work with open and bagging experiments also showed that the probable mode of pollination is cross pollination although selfing is also present [24].

Various molecular marker (protein and nucleic acidbased) techniques have been widely used in genetic studies of wild plant populations. Such techniques enable researchers to answer questions pertinent to speciation, within and between population genetic diversity, gene flow and level of outcrossing [25]. Although co-dominant markers such as isozymes, Restriction Fragment Length Fragments (RFLPs) and Simple Sequence Repeats (SSRs) are particularly useful in wild populations, dominant markers such as RAPD and Amplified Fragment Length Polymorphism (AFLP) have also been applied widely and efficiently [26]. In the present study, RAPD marker system has been employed because of its simplicity, rapidity, low cost and non-requirement of sequence information for primer design $[27,28]$. RAPDs have been used in the genetic diversity analyses and diagnostic marker development for species or population of various food crops, weeds, medicinal and aromatic plants [29-33] as well as in gene tagging of disease resistant genes and Marker assisted selection [30,34].

Genetic architecture of population is generally believed to be the resultant of breeding system, gene flow within and between population, isolation mechanism and continued selection by various natural and artificial forces [35]. Genetic variation in any taxon is not uniformly distributed throughout the geographic area, where it is currently growing and populations growing in areas wide by geographical separation are expected to accumulate enormous genetic diversity. Therefore, for the assessment of genetic diversity, genotypes collected from different geographical locations have to be considered which enables capturing of all sorts of allelic diversity of a particular taxon.

So far, no molecular approaches have been employed to assess the level of genetic diversity in S. chirayita populations from different geographical locations of Nepal. Present investigation was undertaken to assess genetic diversity of $S$. chirayita populations representing East, Central and Western development regions of Nepal using genome-based RAPD technique.

\section{Material and Methods}

\subsection{Plant Materials}

DNA samples of 34 accessions of S. chirayita and 6 outlier species were collected in Silica gel from their natural habitats of five districts representing eastern, central and western development regions of Nepal (Table 1 and Figure 1). Herbarium specimens of all these samples were also collected for their taxonomic identification.

Each herbarium and DNA sample was designated with accession code with respect to the site of collections and the collected samples were brought to the Molecular Biotechnology Laboratory of Nepal Academy of Science and Technology (NAST) for DNA extraction and subsequent molecular analysis.

\subsection{DNA Extraction and Quantification}

Genomic DNA from various samples were extracted by using Hexadecyltrimethyl Ammonium Bromide (CTAB) method [36]. Quantification and purity assessments of 
Table 1. Sample details of $S$. chirayita and other outlier species used in present investigation, locality of collection, number of samples collected, altitude of collection and plant accession codes.

\begin{tabular}{clcccc}
\hline S. $\mathbf{N}$ & \multicolumn{1}{c}{ District/Locality } & $\begin{array}{c}\text { Region of } \\
\text { Nepal }\end{array}$ & No. of samples collected & Altitude (meters) & \multicolumn{1}{c}{ Plant Accession Code } \\
\hline $\mathbf{1}$ & Lalitpur/Phulchowki, Godavari & Central & 9 & $2100-2150$ & $\begin{array}{l}\mathrm{F}_{1}, \mathrm{~F}_{2}, \mathrm{~F}_{3}, \mathrm{~F}_{4}, \mathrm{~F}_{5}, \mathrm{~F}_{6}, \mathrm{~F}_{7}, \mathrm{~F}_{8} \\
\text { and } \mathrm{F}_{9} .\end{array}$ \\
$\mathbf{2}$ & Kaski/Sikles & Western & 4 & $2000-2500$ & $\mathrm{~K}_{501}, \mathrm{~K}_{505}, \mathrm{~K}_{506}$ and $\mathrm{K}_{509}$. \\
$\mathbf{3}$ & Kaski/Sikles & Western & 4 & $2000-2500$ & $\mathbf{K}_{511}, \mathbf{K}_{512}, \mathbf{K}_{516}$ and $\mathbf{K}_{517}$ \\
$\mathbf{4}$ & Kathmandu/Nagarjun, Jamacho & Central & 7 & $2050-2100$ & $\mathrm{~N}_{7}, \mathrm{~N}_{8} \mathrm{~N}_{12}, \mathrm{~N}_{14}, \mathrm{~N}_{15}, \mathrm{~N}_{16}$ \\
and $\mathrm{N}_{20}$
\end{tabular}

Note: Bolded sample accessions were used as outlier species in the present investigation $\left(\mathbf{K}_{\mathbf{5 1 1}}\right.$ and $\mathbf{K}_{\mathbf{5 1 2}}$ : Swertia dilatata; SA and $\mathbf{K}_{\mathbf{5 1 6}}$ : Swertia nervosa; $\mathbf{S B}$ and $\mathrm{K}_{517}$ : Swertiape dicellata).

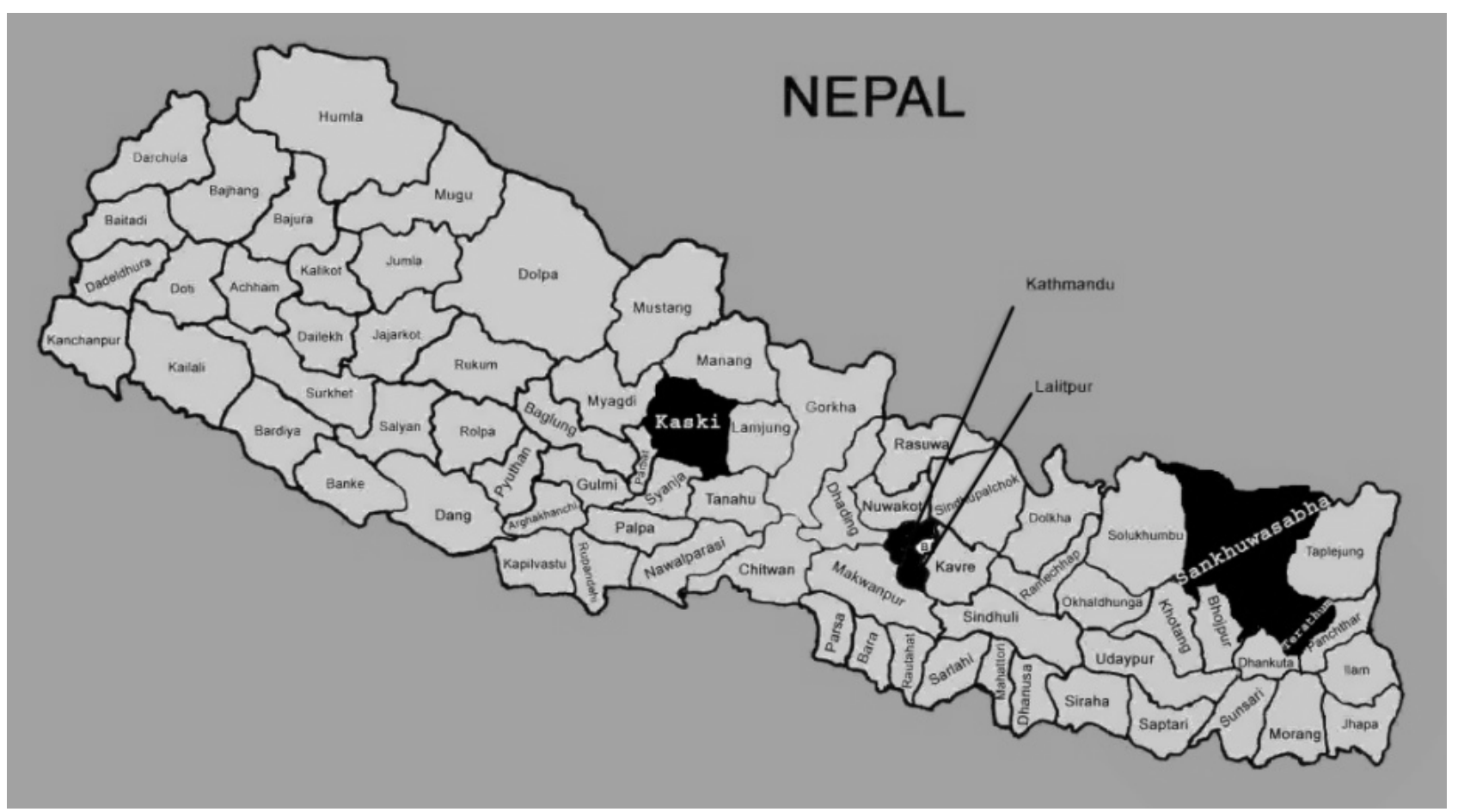

Figure 1. Sampling sites of the present study.

extracted DNA were performed by using a UV Biophotometer (EPPENDORF AG 22331, Germany).

\subsection{PCR Amplification}

RAPD-PCR reaction parameters were optimized in $25 \mu \mathrm{l}$ reaction volume by varying concentrations of template DNA, $\mathrm{MgCl}_{2}$, dNTPs, primers and Taq DNA polymerase. Best cycling condition was chosen between the two RAPD-PCR cycling conditions described by Yu and Pauls
(1992) and Edwards (1998) [37,38]. The best reaction and cycling parameters producing distinct scorable band profiles was then selected for subsequent RAPD profiling experiments. DNA amplifications were performed in BIOER Xp thermal cycler [BIOER Technology Co. LTD, Taiwan, China].

The PCR amplified RAPD fragments were separated by gel electrophoresis using $1.5 \%$ agarose in $1 \mathrm{X}$ TAE (Tris, Acetic acid and EDTA) buffer at $25 \mathrm{~V}(4.2 \mathrm{~V} / \mathrm{cm})$ in EMBI TEC (Santiago, CA) gel tank for one and half 
hour. The gel were then stained in TAE buffer containing $35 \mu \mathrm{L}$ of Ethidium bromide $(10 \mathrm{mg} / \mathrm{mL}$ solution, PROMEGA Co.) for 45 min followed by 15 mins destaining in water prior to gel documentation using Gel Doc system (IN GENIUS, Syngene Bioimaging, UK).

\subsection{RAPD Profiling}

Initially, 100 decamer primers (from UBC primer set-1, University of British Columbia, Oligonucleotide Synthesis Laboratory, Vancouver, British Columbia, Canada) were screened against fresh genomic DNA of Swertia chirayita from Kaski district. Twenty six UBC primers (Table 2) that gave reproducible and scorable amplifications were finally selected for the RAPD-PCR profiling involving all 40 accessions under study. All the accessions under study were screened with each of the 26 random primers to generate banding profiles for the genetic diversity study.

RAPD profiles generated by all 26 primers were used for the band scoring and binary data matrix creation. All polymorphic and monomorphic bands were scored. Markers were scored visually as discrete variables ("1" for presence and "0" for absence). Amplification failure was scored as "9", which was designated in the analysis procedure as an indicator of missing data [39]. Molecular size of the PCR products was determined by comparing the position of bands with Gene ruler $^{\mathrm{TM}} 100 \mathrm{bp}$ plus DNA ladder (FERMENTAS company).

\subsection{Data Analysis}

The binary data matrix created was analysed using MSExcel 2007 for the estimation of the banding characteristics namely: 1) Total number of bands (TNB), 2) number of polymorphic bands (NPB), 3) Percent Polymorphism (PP), 4) Polymorphic Information Content (PIC), 5) Band Informativeness $\left(\mathrm{I}_{B}\right)$, and 6) Resolving Power $\left(\mathrm{R}_{\mathrm{P}}\right)$ for each primer used, which are defined by, $\mathrm{PP}=$ NPB/TNB generated by each primer; PIC $=1-\sum\left(P_{i j}\right)^{2}$, where $P_{i j}$ is the frequency of the $i^{\text {th }}$ pattern revealed by the $\mathrm{j}^{\text {th }}$ primer summed across all patterns revealed by the primers $[40] ; \quad I_{B}=1-[2 \times(0.5-P)]$, where $\mathrm{P}$ is the proportion of accessions containing the band. $R_{P}$ was calculated as $R_{P}=\sum I_{B}[41]$.

Within and between population genetic diversity estimation was computed using NTSYS (Numerical Taxonomy and Multivariate System, version 2.21i, Exeter software; Setauket, New York, USA). Similarity indices were calculated applying a similarity for qualitative data (SIMQUAL) computer algorithm using NTSYS-PC. From these similarity indices, sequential, agglomerative, heirarchial and nested (SAHN) clustering was performed using the unweighted pair group method of arithmetic averages algorithm (UPGMA) [42]. Estimates of similarity were computed based on three different measures: 1) simple Matching coefficient (SM) [43], $S_{i j}=\frac{a+d}{a+b+c+d}$; 2) Dice's coefficient of similarity(D) [44], $S_{i j}=\frac{2 a}{2 a+b+c}$; 3) Jaccard's coefficient (J) [45], $S_{i j}=\frac{a}{a+b+c}$ where, $\mathrm{S}_{\mathrm{ij}}=$ the similarity between two individuals, $\mathrm{i}$ and $\mathrm{j} ; \mathrm{a}=$ the number of bands present in both $i$ and $j$; $b$ is the number of bands present in $\mathrm{i}$ and absent in $\mathrm{j}$; $\mathrm{c}$ is the number of bands present in $j$ and absent in $i$, and $d$ is the number of bands absent from both $i$ and $j$.

Original matrices of SM, J and D coefficients were compared by Mantel test [46] using MXCOMP option in NTSYS program. Similarly, the correlation between the similarity matrices and its corresponding phenograms were estimated with the cophenetic correlation test. The estimated correlation matrices show the goodness of fit of cluster analysis in accordance with similarity matrix. Also, the phenograms generated from different coefficients were compared by consensus fork Index $\left(\mathrm{CI}_{\mathrm{c}}\right)$ that estimates the dendogram similarities and measure how well resolved the tree is [47]. Best fitted coefficient of similarity matrix was employed for the diversity assessment. Relationships among the S. chirayita individuals were also studied using a Principal Coordinate Analysis (PCoA) using Multivariate statistical package (MVSP 3.2).

\section{Results}

The optimized RAPD-PCR reaction parameters consisted of DNA (25 ng), $\mathrm{MgCl}_{2}(3.0 \mathrm{mM}), 10 \mathrm{X}$ Taq polymerase reaction buffer $[2.5 \mu \mathrm{l} ; 100 \mathrm{mM}$ Tris- $\mathrm{HCl}(\mathrm{pH} 8.8$ at $25^{\circ} \mathrm{C}$ ), $500 \mathrm{mM} \mathrm{KCl}, 0.8 \%$ (v/v) Nonidet P40], Taq DNA polymerase (1U, MBI FERMENTAS company), dNTPs $(0.2 \mathrm{mM}$ each) and primer $(0.4 \mu \mathrm{M})$ in $25 \mu \mathrm{l}$ PCR reaction volume.

PCR cycling conditions described by Edwards (1998) produced best banding profile for $S$. chirayita and hence selected for subsequent PCR amplifications. Program consisted of an initial denaturation step at $95^{\circ} \mathrm{C}$ for 2 min followed by 45 cycles of $95^{\circ} \mathrm{C}$ for $20 \mathrm{~s}, 37^{\circ} \mathrm{C}$ for $60 \mathrm{~s}$ and $72^{\circ} \mathrm{C}$ for $60 \mathrm{~s}$ and final extension of $72^{\circ} \mathrm{C}$ for $10 \mathrm{~min}$.

\subsection{RAPD Analysis}

Primer screening involving 100 decamer primers resulted into 26 primers (Table 2) that produced scorable, reproducible and unambiguous polymorphic bands. The 26 
Table 2. Primer sequences, Total Number of Bands (TNB), Number of Polymorphic Bands (NPB), Percentage Polymorphism (PP), amplicon size range, PIC, $I_{B}$ and $R_{P}$ values of the 26 RAPD primers used to generate RAPD profiles of Swertia chirayita accessions.

\begin{tabular}{|c|c|c|c|c|c|c|c|c|}
\hline Primer code & Primer Sequence ( $\left.5^{\prime}-3{ }^{\prime}\right)$ & TNB & NPB & PP & Amplicon size range (bp) & PIC & $\mathbf{I}_{\mathbf{B}}$ & $\mathbf{R}_{\mathbf{P}}$ \\
\hline UBC 2 & CCTGGGCTTG & 13 & 13 & 100.00 & $400-2500$ & 0.90 & 0.95 & 13.29 \\
\hline UBC 3 & CCTGGGCTTA & 15 & 15 & 100.00 & $350-2800$ & 0.90 & 0.68 & 10.18 \\
\hline UBC 6 & CCTGGGCCTA & 13 & 13 & 100.00 & $300-2100$ & 0.91 & 1.20 & 16.28 \\
\hline UBC 51 & CTACCCGTGC & 7 & 4 & 57.14 & $500-2500$ & 0.67 & 1.0 & 5.0 \\
\hline UBC 85 & GTGCTCGTGC & 9 & 6 & 66.67 & $450-1900$ & 0.84 & 0.90 & 8.12 \\
\hline UBC 18 & GGGCCGTTTA & 9 & 9 & 100.00 & $200-2000$ & 0.84 & 0.96 & 8.65 \\
\hline UBC 74 & GAGCACCTGA & 8 & 8 & 100.00 & $450-200$ & 0.83 & 0.99 & 7.94 \\
\hline UBC 76 & GAGCACCAGT & 11 & 11 & 100.00 & $400-2150$ & 0.89 & 0.79 & 9.53 \\
\hline UBC 23 & CCCGCCTTCC & 11 & 8 & 72.73 & $500-2400$ & 0.84 & 0.95 & 8.59 \\
\hline UBC 43 & AAAACCGGG & 13 & 13 & 100.00 & $450-3600$ & 0.85 & 0.74 & 9.65 \\
\hline UBC 65 & AGGGGCGGGA & 14 & 14 & 100.00 & $400-2700$ & 0.86 & 0.63 & 8.82 \\
\hline UBC 97 & ATCTGCGAGC & 13 & 13 & 100.00 & $500-2000$ & 0.84 & 0.47 & 6.06 \\
\hline UBC 86 & GGGGGGAAGG & 9 & 9 & 100.00 & $350-2400$ & 0.86 & 0.81 & 8.06 \\
\hline UBC 4 & CCTGGGCTGG & 10 & 8 & 80.00 & $450-1900$ & 0.84 & 1.10 & 9.94 \\
\hline UBC 73 & GGGCACGCGA & 10 & 10 & 100.00 & $600-2000$ & 0.81 & 0.55 & 5.53 \\
\hline UBC 67 & GAGGGCGAG & 9 & 6 & 66.67 & $400-2000$ & 0.81 & 0.94 & 7.53 \\
\hline UBC 15 & CCTGGGTTTG & 12 & 12 & 100.00 & $450-2500$ & 0.87 & 0.64 & 8.35 \\
\hline UBC 16 & GGTGGCGGGA & 12 & 10 & 83.33 & $400-2000$ & 0.87 & 1.01 & 11.06 \\
\hline UBC 54 & GTCCCAGAGC & 11 & 11 & 100.00 & $550-2600$ & 0.87 & 0.76 & 9.18 \\
\hline UBC 66 & GAGGGCGTGA & 11 & 9 & 81.82 & $400-1700$ & 0.82 & 0.70 & 7.65 \\
\hline UBC 71 & GAGGGCGAGG & 11 & 10 & 90.91 & $300-1800$ & 0.89 & 1.22 & 13.41 \\
\hline UBC 88 & CGGGGGATGG & 10 & 9 & 90.00 & $400-3000$ & 0.87 & 1.02 & 10.18 \\
\hline UBC 96 & GGCGGCATGG & 12 & 10 & 83.33 & $450-1600$ & 0.89 & 1.09 & 11.06 \\
\hline UBC 92 & CCTGGGCTTT & 13 & 13 & 100.00 & $350-2700$ & 0.90 & 0.38 & 4.94 \\
\hline UBC 55 & TCCCTCGTGC & 14 & 14 & 100.00 & $550-2000$ & 0.90 & 0.52 & 7.29 \\
\hline \multirow[t]{2}{*}{ UBC 17} & CCTGGGCCTC & 5 & 5 & 100.00 & $600-2200$ & 0.74 & 0.40 & 2.41 \\
\hline & Total & 285 & 263 & & Average & 0.85 & 0.82 & 8.8 \\
\hline
\end{tabular}

primers generated a total of 285 RAPD loci across $34 \mathrm{~S}$. chirayita accessions, with an average amplification of $\approx 11$ bands per primer (Figure 2). Of these, 263 (92.28\%) bands were polymorphic. Individually, polymorphic bands produced by each primer ranged from $57.14 \%$ to $100 \%$. Sixteen out of twenty six primers furnished $100 \%$ polymerphic bands (Table 2). The number of scorable bands produced per primer ranged from 5 to 15 with amplicon size ranging from $200 \mathrm{bp}$ to $3600 \mathrm{bp}$.
PIC score for each primer ranged from 0.67 (UBC 51) to 0.91 (UBC 6) with an average of 0.85 (Table 2). The primers scoring PIC value more than 0.85 were UBC: 6 , $2,3,92,55,96,71,76,54,16,15,86,65$ and 43 in decreasing order of their values. The average Band Informativeness $\left(\mathrm{I}_{\mathrm{B}}\right)$ of the 26 primers was 0.82 and it ranged from 0.38 (for $U B C$ 92) to 1.22 (UBC 71). The $R_{P}$ of the 26 RAPD primers ranged from 2.41 for primer UBC 17 to 16.28 for primer UBC 6 with an average of 8.80 . UBC 
primers $2,3,16,71,88$ and 96 furnished $R_{P}$ values more than 10 (Table 2).

\subsection{Genetic Diversity Assessment among Different Populations of $S$. chirayita}

The varied ranges of similarity were obtained, using SM (0.65 - 0.96), J (0.26 - 0.89) and D (0.42 - 0.94) with an average similarity coefficient value of $0.81,0.58$ and 0.68 respectively. The results from Mantel test of original matrices showed that the correlation between Jaccard and Dice similarity matrices was the highest and significant (0.92224) (Table 3).

Cophenetic correlations between the genetic similarity matrices and cophenetic matrices are shown (Table 4). UPGMA clustering for Jaccard coefficient had the highest cophenetic correlation value of 0.85012 compared to Dice and Simple Matching coefficients. Because of the highest correlation value, Jaccard's coefficient of similarity is evaluated to be the best for deducing the genetic

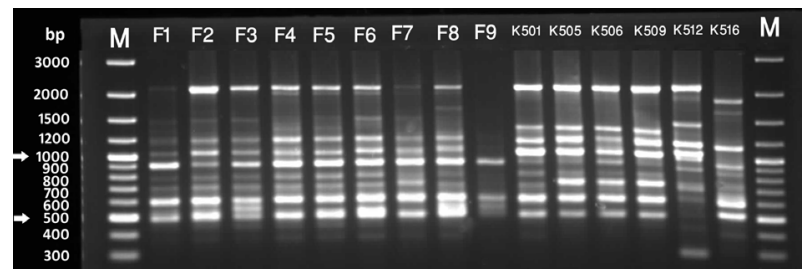

(a)

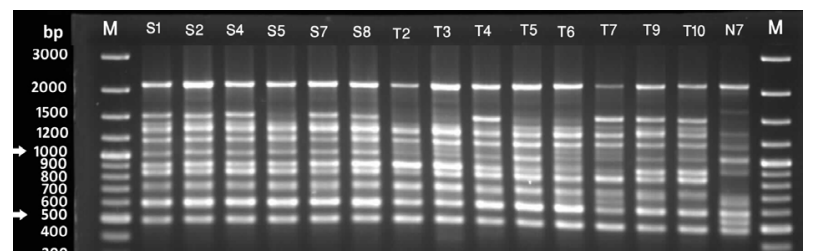

(b)

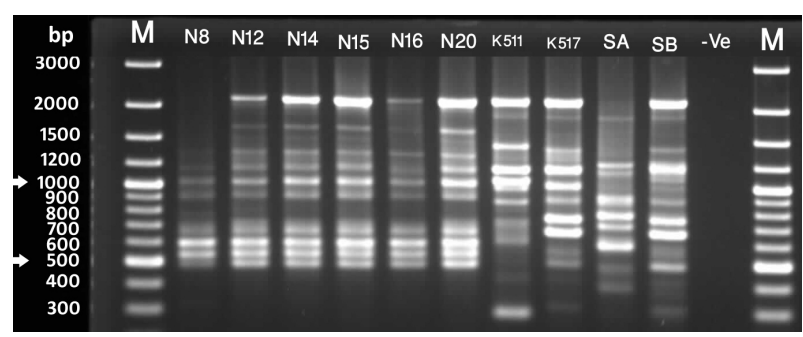

(c)

Figure 2. RAPD profile generated by primer UBC 6. Lanes marked with $M$ are $100 \mathrm{bp}$ plus molecular weight markers. [A] Lanes $F_{1}-F_{9}$ are $S$. chirayita accessions from Phulchowki, $K_{501}-K_{509}$ are $S$. chirayita from Kaski, $K_{512}$ is $S$. dilatata and $\mathrm{K}_{516}$ is Swertia nervosa from Kaski [B] $\mathrm{S}_{1}-\mathrm{S}_{\mathbf{8}}$ are $S$. chirayita accessions from Sankhuwasbha; $T_{2}-T_{10}$ are $S$. chirayita accessions from Terathum; $\mathrm{N}_{7}$ is $S$. chirayita accession from Nagarjun [C] $\mathrm{N}_{8}-\mathrm{N}_{20}$ are $S$. chirayita accessions from Nagarjun; $K_{511}$ is $S$. dilatata; $K_{517}$ and $S B$ are $S$. pedicellata and SA is Swertia nervosa. relationship among various $S$. chirayita accessions using UPGMA algorithm.

Also, the results obtained from consensus indices showed that consensus fork index was the highest $\left(\mathrm{CI}_{\mathrm{C}}=\right.$ 0.9063) for Jaccard and Dice coefficients (Table 5).

From all the comparisons made for similarity coefficients, Jaccard's coefficient was finally chosen as the best to interpret the results of genetic diversity among $S$. chirayita accessions. On the basis of Jaccard's similarity matrix, genetic similarities (\%) were estimated between the $S$. chirayita populations. From the pairwise comparisons, $S$. chirayita accessions from Terathum: $\mathrm{T}_{2}$ and $\mathrm{T}_{3}$ were observed to be closest ( $89 \%$, genetic similarity) and the accessions from Terathum $\left(\mathrm{T}_{4}\right)$ and Nagarjun $\left(\mathrm{N}_{8}\right)$ were revealed to be the most distant with genetic similarity value of $26 \%$. The overall average genetic similarity value based on pairwise comparisons of 34 S. chirayita accessions was $49 \%$ (data not shown). Swertia chirayita populations from Sankhuwasabha and Terathum were found to be closest with $68 \%$ of mean genetic similarity (MGS) whilst accessions from Nagarjun and Terathum were found to be most distant with only $33 \%$ of MGS (Table 6).

\subsection{Phenogram and PCoA Based Cluster Analysis}

Figure 3 represents the phenogram constructed for 34

Table 3. Correlation coefficients from mantel test of original similarity matrices.

\begin{tabular}{cccc}
\hline & Simple Matching & Jaccard & Dice \\
\hline Simple Matching & $* * * * *$ & & \\
Jaccard & 0.07056 & $* * * * *$ & \\
Dice & 0.31292 & 0.92224 & $* * * * *$ \\
\hline
\end{tabular}

Table 4. Cophenetic correlation coefficients obtained for similarity matrices and cophenetic matrices of clusters computed by UPGMA module using MXCOMP (matrix comparisons) option of NTSYS.

\begin{tabular}{cccc}
\hline $\begin{array}{c}\text { Clustering modules } \\
\text { of similarity }\end{array}$ & $\begin{array}{c}\text { Simple } \\
\text { matching }\end{array}$ & Dice & Jacard \\
\hline UPGMA & 0.43580 & 0.84315 & 0.85012 \\
\hline
\end{tabular}

Table 5. Consensus fork indices among the phenograms (UPGMA) produced by similarity coefficients among $S$. chirayita accessions by RAPD marker.

\begin{tabular}{cccc}
\hline & Jaccard & Dice & Simple Matching \\
\hline Jaccard & $* * * * *$ & 0.90625 & 0.71875 \\
Dice & & $* * * * *$ & 0.71875 \\
Simple Matching & & & $* * * * *$
\end{tabular}


accessions of S. chirayita and 6 outlier accessions. Thirty four S. chirayita individuals were found separated into two major sub-clusters at the similarity coefficient of 0.37 . The first sub-cluster contained 20 accessions from Phulchowki, Kaski and Nagarjun populations and the second sub-cluster contained 14 accessions from Sankhuwasabha and Terathum populations. In the first subcluster, Phulchowki and Kaski populations were shown genetically closer to each other than to Nagarjun population. Nagarjun populations were found separated from
Phulchowki and Kaski populations at similarity coefficient of 0.44 . In the phenogram, all five populations of $S$. chirayita under study clustered distinctly according to geographical distribution. The S. chirayita individuals within a population were clustered into a group at different similarity coefficient levels, viz. Phulchowki populations at 0.61 , Kaski at 0.73 , Nagarjun at 0.56, Sankhuwasabha at 0.78 and Terathum at 0.65 . On the contrary, clear delineation between $S$. chirayita and different outliers were visible in the phenogram (Figure 3).

Table 6. Mean genetic similarity (GS) of the $S$. chirayita accessions from five different populations based on RAPD similarity matrix (J).

\begin{tabular}{cccccc}
\hline Populations & Phulchowki & Kaski & Sankhuwasabha & Terathum & Nagarjun \\
\hline Phulchowki & $57 \%$ & $41 \%$ & $38 \%$ & $45 \%$ & $45 \%$ \\
Kaski & & $38 \%$ & $38 \%$ & $34 \%$ \\
Sankhuwasabha & & & $68 \%$ & $33 \%$ \\
Terathum & & & \\
Nagarjun & & & \\
\hline
\end{tabular}

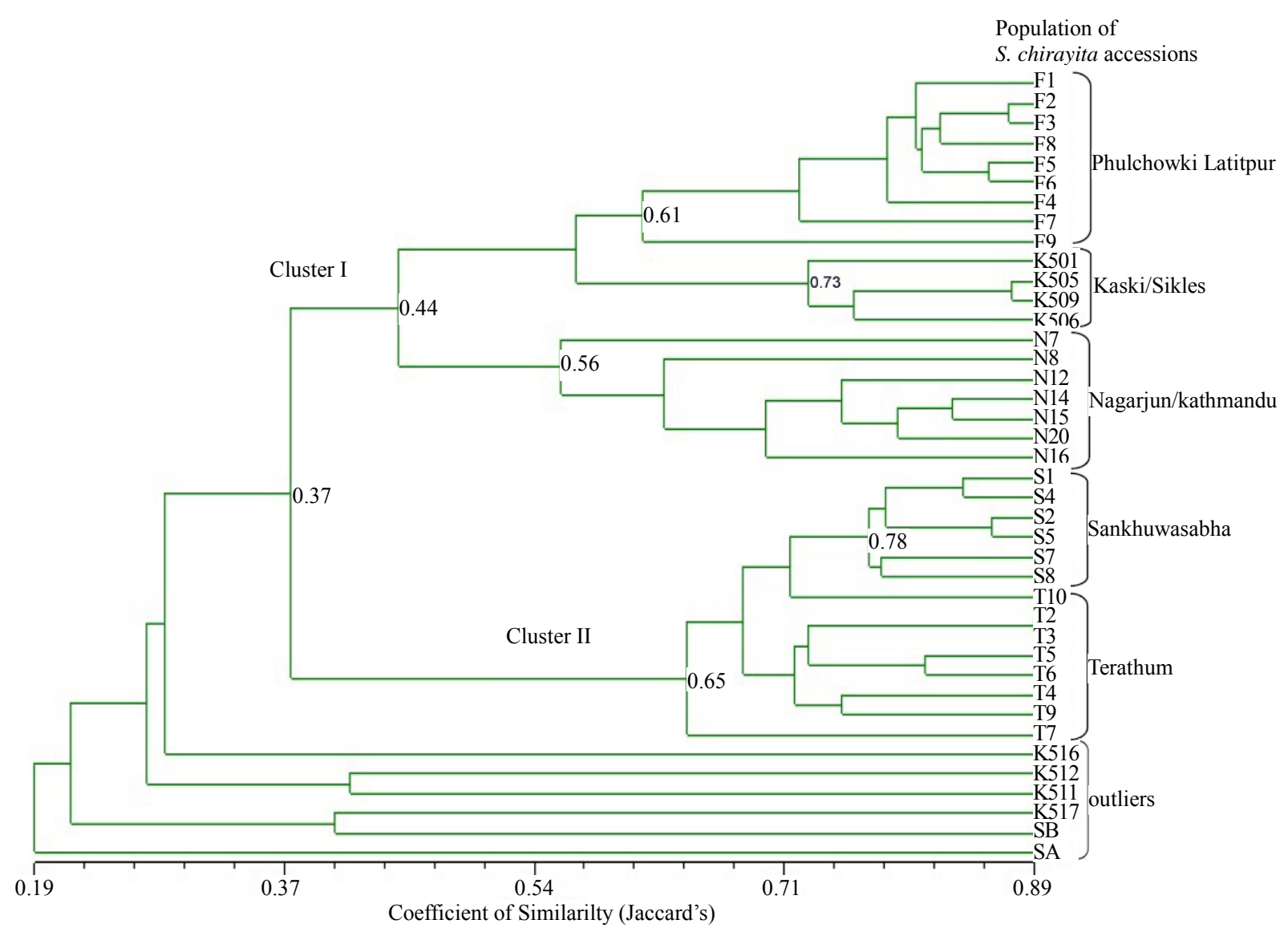

Figure 3. Phenogram generated for 34 Swertia chirayita accessions and six outlier accessions as revealed by UPGMA cluster analysis using Jaccard's similarity coefficient. Binary data matrix created for 386 RAPD loci generated by 26 primers was used for the analysis. Two main clusters in S. chirayita are labeled as I and II. 
In order to substantiate the genetic relationships among the samples collected, a PCoA analysis based on the Euclidean matrix was carried out (Figure 4). The first (Eigen value $=29.537$; percentage of variance $=38.3 \%$ ) and second (Eigen value $=11.827$; percentage of variance $=$ $15.3 \%$ ) axis with a cumulative variance of $53.6 \%$ was observed. Plots of the first two coordinates were used for generating a PCoA graph (Figure 4) which supports the result of phenogram by clustering the individuals according to their geographical locations. Swertia chirayita from Sankhuwasabha and Terathum grouped together in one cluster whereas from phulchowki, Kaski and Nagarjun samples grouped into another cluster.

\section{Discussion}

All present day crop germplasms are products of domestication from the wild, long term selection and breeding for the improvement of desirable agronomic traits. Domestication followed by continued breedings selection for elite germplasms is an integral part of present day plant breeding [48]. Recently, developed molecular marker techniques have greatly complemented conventional breeding for crop improvement. Genetic diversity assessments using molecular tools help to analyze genetic variability among populations, select parental materials for hybridization for making new genetic recombination, select inbred parents for maximizing heterotic responses and identify materials that should be maintained for preservation of maximum genetic diversity in germplasm collections [49]. For all these applications, a simple and cost effective method for determination of genetic diversity relationships based on comparisons involving entire genomes is needed. In recent decades, a variety of molecular techniques and genetic markers have been extensively developed to estimate genetic diversity, but no single technique is universally ideal and each available technique exhibits both strengths and weaknesses. Therefore, the choice of technique is often a compromise that depends on the research question pursued and the genetic resolution needed [25]. Although it has been held, dominant marker like RAPD is not suitable for genetic analyses necessitating information on allele frequencies, they are appropriate in cases where allele frequency data are not needed. RAPD-marker system is a valuable tool for addressing genetic diversity, population genetics and plant breeding issues [50]. RAPD detects polymorphisms at DNA sequence level and has been widely applied in various disciplines [29,30,32,34]. RAPD provides a powerful tool to discriminate the closely related species even down to the level of subspecies [51].

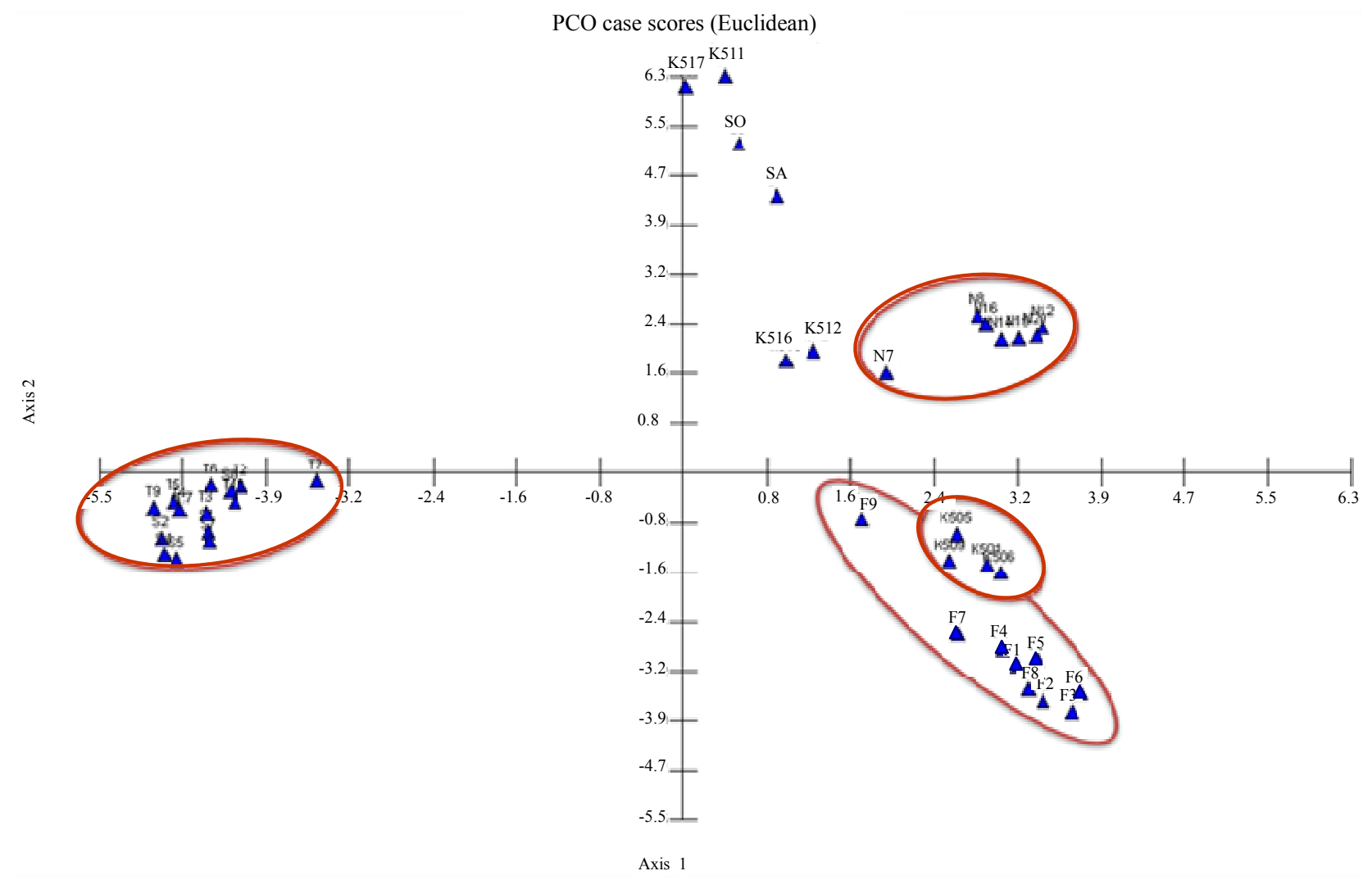

Figure 4. Principle coordinate analysis of 40 accessions of Swertia using MVSP 3.2. 
Swertia chirayita being one of the most important medicinal plants of Nepal having high demand in national/ international markets, natural populations of this species have become vulnerable. Although its domestication has started at various locations, scientific studies aiming at assessing genetic diversity of various populations and assessment of superior genotypes in terms of their chemical properties are still lacking. In this context, information on genetic diversity assessment of germplasm has several important applications for plant biologists, plant breeders, biotechnologists, chemists and conservationists [2,25,49, 50].

\subsection{RAPD Analysis}

The genetic polymorphism observed in the present RAPD investigation for S. chirayita is very high (i.e. 92.28\%) in comparison to the value observed for Indian S. chirayita using ISSR marker. The genetic diversity study carried out in S. chirayita from temperate Himalaya of India involving ISSR markers indicated only $42.5 \%$ of polymorphic bands [52]. In the similar study of intra-specific genetic variation pattern in endangered endemic species, Swertia przewalskii of Qinghai-Tibet plateau, the genetic polymorphism was observed to be $52 \%$ for RAPD and $56 \%$ for ISSR marker [53]. Genetic polymorphism shown with RAPD analysis was 56\% for Brassica carinata [54]; $82.61 \%$ for Anisodus tanguticus [55] and 52.85\% for Trigonellafoenum-graecum [56].

The study reports that some of the primers were more useful than others for distinguishing accessions. Higher the PIC, $I_{B}$ and $R_{P}$ values, superior is the discriminating power of primer used [54,57]. PIC value higher than 0.5 indicates a highly polymorphic locus [40]. Amplification profiles for most of the UBC primers $(6,2,3,92,55,96$, 71, 76, 54, 16, 15, 86, 65 and 43) gave a PIC score greater than 0.85 suggesting that these primers are especially useful for RAPD based analyses of genetic diversity in $S$. chirayita. Band informativeness $\left(\mathrm{I}_{\mathrm{B}}\right)$ and the primer resolving power $\left(\mathrm{R}_{\mathrm{P}}\right)$ provide quantitative data allowing direct comparisons between primers [41]. $\mathrm{R}_{\mathrm{P}}$ of the 26 RAPD primers ranged from 2.41 for the primer UBC 17 to 16.28 for the primer UBC 6 with average estimate of 8.8 (Table 2). As compared to values reported for other plants, mean PIC score $(0.85)$ and $R_{P}$ score (8.8) in this study were comparatively higher $[22,54,58]$.

\subsection{Genetic Diversity Assessment and Cluster Analysis}

It was suggested when the marker data are "allelic noninformative", the estimates of coefficients between OTUs under consideration can be calculated by one of the three coefficients, based on the absence or presence of ob- served bands viz. Dice's similarity coefficient (D) is equivalent to Nei-Li coefficient [60]; Jaccard's similarity coefficient (J) [45] and Simple matching similarity coefficient (SM) [43] after examining 10 similarity coefficients are widely used in germplasm surveys [59]. In contrast to SM, both J and D do not involve shared absence of DNA bands. Thus, comparisons of these three similarity coefficient matrices and clustering methods seem imperative to find out the most fitted matrix for the discrimination of genetic diversity using RAPD profiles. Similarity matrices based on $\mathrm{J}$ and $\mathrm{D}$ were highly correlated $(\mathrm{r}>0.92)$ according to Mantel matrix correspondence test together with the high correlation of their phenograms as given by Consensus index ( $r>0.9)$. Comparing Cophenetic correlations between the genetic similarity matrices and cophenetic matrices, UPGMA clustering for $\mathrm{J}$ had the highest cophenetic correlation value $(r>0.85)$ than D and SM coefficients. According to Rohlf (2009), if the cophenetic correlation values, $\mathrm{r}$ is such that $0.8 \leq \mathrm{r}<0.9$, the similarity coefficient is interpreted as good fit for determination of genetic variability. Because of the highest correlation value, Jaccard's coefficient of similarity is evaluated as the best for deducing the genetic relationship among various $S$. chirayita accessions using UPGMA module and hence this has been employed for diversity assessment. In a similar study of Sesamum indicum L. using RAPD technique [61], presence of high genetic diversity was observed with Jaccard's coefficient ranging from 0.19 to 0.89 . The present study also revealed the similar range of Jaccard's similarity coefficient of 0.26 to 0.89 reflecting the high genetic diversity within $S$. chirayita accessions coming from various geographical populations. This is in contrary to the low diversity observed with ISSR marker based similarity values of Jaccard's coefficient (i.e. 0.68 to 0.97 ) among $S$. chirayita accessions from temperate Himalaya of India [52].

Among the five populations investigated, the mean genetic similarity among the $S$. chirayita populations varied from 33\% (for Nagarjun and Terathum) to 68\% (for Sankhuwasabha and Terathum) (Table 6). Lower the MGS, higher is the genetic diversity between those accessions. Higher the genetic distance, more ideal will be the accessions to be used as parents in hybridization, to develop improved new elite varieties [62]. The considerably high genetic diversity observed might be the synergistic consequences of cross pollination between the individuals in the population and act of evolutionary forces (natural selection, genetic drift and mutation) in the global climate change perspective [63]. This may be reflecting the good survival potential of the species in the existing environment and also demonstrating fine degree of adaptability and acclimatization in the new selection pressure brought about by environmental changes. In addition to disease 
resistance, greater genetic diversity leads to greater productivity in plant communities, greater nutrient retention as well as ecosystem stability [64]. The knowledge thus generated on the genetic diversity among $S$. chirayita accessions can play a crucial role towards their conservation and elite cultivar development.

In conclusion, the present molecular study based on RAPD highlighted that the high levels of genetic diversity are still maintained among $S$. chirayita accessions in different populations. Despite its vulnerable status, it has got the potential to adapt in its existing environment if the over encroachment by human is controlled. All these populations need to be judiciously conserved ex situ (e.g. in seed banks) as well as in situ in their natural habitats and sustainable harvesting practices must be followed for long term survival of this species. Furthermore, relevant laws should be strictly enforced to restrict the rampant exploitation of the species beyond its regeneration capacity that is still threatening many populations of valuable species in their natural habitats.

The genetic diversity estimates generated from the present study on the basis of RAPD data have not only highlighted the inherent genetic relationship among five populations under study but also produced data on intraspecific polymorphic nature of $S$. chirayita accessions. Present investigation has opened up new avenues of academic research in the field of high value germplasm characterization, documentation, conservation and sustainable utilization in Nepal.

\section{Acknowledgements}

Authors would like to acknowledge Ministry of Science and Technology, Government of Nepal for providing necessary funds to run this project. Authors would also like to thank Nepal Academy of Science and Technology (NAST) for supporting this project.

\section{REFERENCES}

[1] S. K. Ghimire, "Medicinal Plants in the Nepal Himalaya: Current Issues, Sustainable Harvesting, Knowledge Gaps and Research Priorities,” In: P. K. Jha, S. B. Karmacharya, M. K. Chhetri, C. B. Thapa and B. B. Shrestha, Eds., Medicinal Plants in Nepal: Anthology of Contemporary Research, Ecological Society (ECOS), Kathmandu, Nepal, 2008, pp. 25-42.

[2] DPR, "Prioritized Medicinal Plants of Nepal for Research and Cultivation," Department of Plant Resources Publication, Ministry of Forests and Soil Conservation, Government of Nepal, 2005.

[3] L. Struwe and V. A. Albert, "Gentianaceae-Systematics and Natural History," Cambridge University Press, Cambridge, 2002.

[4] K. Joshi, "Molecular Differentiation and Phylogeny of
Swertia (Gentianaceae) of the Himalayan Region, Nepal," International Journal of Biotechnology and Biochemistry, Vol. 7, No. 2, 2011, pp. 265-277.

[5] J. R. Press, K. K. Shrestha and D. A. Sutton, "Annotated Checklist of the Flowering Plants of Nepal," The Natural History Museum, London, 2000, pp. 117-119.

[6] D. P. Rijal, "Taxonomic Study of Some Medicinally Important Species of Swertia L. (Gentianaceae) in Nepal," Botanica Orientalis-Journal of Plant Science, Vol. 6, 2009, pp. 18-24.

[7] T. P. Barakoti, T. Chapagain, Y. Thapa and C. Bhusal, "Chiraito Conservation and Cultivation Workshop and Achievement," Nepal Agriculture Research Centre, Pakhribas, 1999.

[8] T. P. Barakoti, "Commercial Cultivation and Production Management of Chiraito: Scheme Guide," ARS Pakhribas, Nepal Agricultural Research Council, Nepal, 2002, pp. 150.

[9] K. Joshi and A. Joshi, "Swertia L. (Gentianaceae) in Nepal Himalaya: Checklist, Phytogeography, Ethnobotany and Conservation Status," Ethnobotanical Leaflets, Vol. 12, 2008, pp. 361-372.

[10] T. P. Barakoti, "Attempts Made for Domestication, Conservation and Sustainable Development of Chiretta (Swertiachirayita)," Nepal Agriculture Research Centre (NARC), Dhankuta, 2004.

[11] S. Phoboo, P. K. Jha and P. C. Bhowmik, "Biology and Phytochemistry of Swertiachirayita," In: P. K. Jha, S. B. Karmacharya, M. K. Chhetri, C. B. Thapa and B. B. Shrestha, Eds., Medicinal Plants in Nepal: Anthology of Contemporary Research, Ecological Society (ECOS), Kathmandu, 2008, pp. 203-211.

[12] M. B. Bajpai, R. K. Asthana, N. K. Sharma, S. K. Chatterji and S. K. Mukherjee, "Hypoglycemic Effect of Swerchirin from the Hexane Fraction of Swertia chirayita," Planta Medica, Vol. 57, No. 2, 1991, pp. 102-104. doi:10.1055/s-2006-960041

[13] N. Pant, D. C. Jain and R. S. Bhakuni, "Phytochemicals from Genus Swertia and Their Biological Activities," Indian Journal of Chemistry, Vol. 39, 2000, pp. 565-586.

[14] P. Joshi and V. Dhawan, "Swertia chirayita-An Overview," Current Science, Vol. 89, No. 4, 2005, pp. 635640.

[15] P. Saha, S. Mandal, A. Das, P. C. Das and S. Das, "Evaluation of Anti-carcinogenic Activity of Swertia chirata Buch. Ham, an Indian Medicinal Plant on DMBAInduced Mouse Skin Carcinogenesis Model," Phytotherapy Research, Vol. 18, No. 5, 2004, pp. 373-378. doi:10.1002/ptr.1436

[16] H. Verma, P. R. Patil, R. M. Kolhapure and V. Gopalkrishna, "Antiviral Activity of the Indian Medicinal Plant Extract, Swertia chirata against Herpes Simplex Virus: A Study by in Vitro and Molecular Approach," Indian Journal of Medical Microbiology, Vol. 26, No. 4, 2008, pp. 322-326. doi:10.4103/0255-0857.43561

[17] S. Phoboo and P. K. Jha, "Trade and Sustainable Conservation of Swertia chirayita (Roxb. Ex Fleming) H. Karst 
in Nepal," Nepal Journal of Science and Technology, Vol. 11, 2010, pp. 125-132.

[18] S. Phoboo, M. D. S. Pinto, A. C. L. Barbosa, D. Sarkar, P. C. Bhowmik, P. K. Jha, et al., "Phenolic-Linked Biochemical Rationale for the Anti-Diabetic Properties of Swertia chirayita (Roxb. Ex Flem) Karst," Phytotherapy Research, Vol. 27, No. 2, 2012, pp. 227-235.

[19] IUCN, "National Register of Medicinal and Aromatic Plants," IUCN Nepal Publication, 2004.

[20] B. Y. Wang, L. Shi, Z. Y. Ruan and J. Deng, "Genetic Diversity and Differentiation in Dalbergiasissoo (Fabaceae) as Revealed by RAPD," Genetics and Molecular Research, Vol. 10, No. 1, 2011, pp. 114-120. doi:10.4238/vol10-1gmr995

[21] O. H. Frankel, "The Place of Management in Conservation," In: C. M. Schonewald-Cox, S. M. Chambers, B. MacBryde and L. Thomas, Eds., Genetics and Conservation: A Reference Manual for Managing Wild Animals and Plant Populations, Benjamin/Cummings, Menlo Park, 1993, pp. 1-14.

[22] V. Arya, S. Yadav and J. P. Yadav, "Intra-Specific Genetic Diversity of Different Accessions of Cassia occidentalis by RAPD Markers," Genetic Engineering and Biotechnology Journal, Vol. 22, 2011, pp. 1-8.

[23] T. N. Khoshoo and S. R. Tandon, "Cytological, Morphological and Pollination Studies on Some Himalayan Species of Swertia," Caryologia, Vol. 16, 1963, pp. 445-477.

[24] S. Chakraborty, D. Mukherjee and T. Dasgupta, "Cytological Study on Chromosome Behaviour and New Report on Nature of Mode of Pollination of Swertia chirayita, a High Value Endangered Medicinal Plant of North Eastern Himalayan Region," Caryologia, Vol. 62, No. 1, 2009, pp. 43-52.

[25] J. C. Avise, "Molecular Markers Natural History and Evolution," 2nd Edition, Sinauer Associates Inc. Publishers, Sunderland, 2004.

[26] K. Weising, H. Nybom, K. Wolff and G. Kahl, "DNA Fingerprinting in Plants Principles, Methods and Applications," 2nd Edition, Taylor \& Francis Group, Boca Raton, London, New York, Singapore, 2005. doi:10.1201/9781420040043

[27] J. G. K. Williams, A. R. Kubelik, K. J. Livak, J. A. Rafalski and S. V. Tingey, "DNA Polymorphisms Amplified by Arbitrary Primers Are Useful as Genetic Markers," Nucleic Acids Research, Vol. 18, No. 22, 1990, pp. 6531-6535. doi:10.1093/nar/18.22.6531

[28] T. E. Dowling, C. Moritz, J. D. Palmer and L. H. Rieseberg, "Nucleic Acids III: Analysis of Fragments and Restriction Sites," In: D. M. Hillis, C. Moritz and B. K. Mable, Eds., Molecular Systematic, 2nd Edition, Sinauer Associates Inc., Sunderland, 1996, pp. 249-282.

[29] J. P. Clapp, "Species Diagnostics Protocols PCR and Other Nucleic Acid Methods," Humana Press, Totowa, 1996, pp. 25-38.

[30] K. Joshi, P. Chavan, D. Warude and B. Patwardhan, "Molecular Markers in Herbal Drug Technology," Current Science, Vol. 87, No. 2, 2004, pp. 159-165.
[31] S. Shrestha, S. W. Adkins, G. C. Graham and D. S. Loch, "An Identification Tool for the Australian Weedy Sporobolus Species Based on Random Amplified Polymorphic DNA (RAPD) Profiles," Australian Journal of Agricultural Research, Vol. 56, No. 2, 2005, pp. 157-167. doi:10.1071/AR04180

[32] H. H. Salem, B. A. Ali, T. H. Huang, D. N. Qin, X. M. Wang and Q. D. Xie, "Use of Random Amplified Polymorphic DNA Analysis for Economically Important Food Crops," Journal of Integrated Plant Biology, Vol. 49, No. 12, 2007, pp. 1670-1680. doi:10.1111/j.1744-7909.2007.00582.x

[33] N. J. Sucher and M. C. Carles, "Genome Based Approaches to the Authentication of Medicinal Plants," Planta Medica, Vol. 74, No. 6, 2008, pp. 603-623. doi:10.1055/s-2008-1074517

[34] S. S. Sandhu, C. Colombo, C. R. Bastos and W. J. Siqueira, "DNA Tagging of Blast Resistant Gene(s) in Three Brazilian Rice Cultivars," Genetics and Molecular Biology, Vol. 26, No. 4, 2003, pp. 473-477. doi:10.1590/S1415-47572003000400011

[35] K. P. S. Chandel and B. S. Joshi, "Multivariate Analysis in Green-Seeded Pea," Indian Journal of Agricultural Science, Vol. 53, No. 4, 1983, pp. 198-200.

[36] G. C. Graham, P. Mayers and R. J. Henry, "A Simplified Method for the Preparation of Fungal Genomic DNA for PCR and RAPD Analysis," BioTechniques, Vol. 16, No. 1, 1994, pp. 48-50.

[37] K. Yu and K. P. Pauls, "Optimisation of the PCR Program for RAPD Analysis," Nucleic Acids Research, Vol. 20, No. 10, 1992, p. 2606. doi:10.1093/nar/20.10.2606

[38] K. J. Edwards, "Randomly Amplified Polymorphic DNAs (RAPDs)," In: A. Karp, P. G. Isaac and D. S. Ingram, Eds., Molecular Tools for Screening Biodiversity-Plants and Animals, Chapman and Hall, London, 1998, pp. 171179. doi:10.1007/978-94-009-0019-6 34

[39] D. K. Transue, D. J. Fairbanks, L. R. Robison and W. R. Andersen, "Species Identification by RAPD Analysis of Grain Amaranth Genetic Resources," Crop Science, Vol. 34, No. 5, 1994, pp. 1385-1389. doi:10.2135/cropsci1994.0011183X003400050044x

[40] D. Botstein, R. L. White, V. Skolnick and V. Davis, "Construction of a Genetic Linkage Map in Man Using Restriction Fragment Length Polymorphisms," American Journal of Human Genetics, Vol. 32, No. 3, 1980, pp. 314-331.

[41] A. Prevost and M. J. Wilkinson, "A New System of Comparing PCR Primers Applied to ISSR Fingerprinting of Potato Cultivars," Theoretical and Applied Genetics, Vol. 98, No. 1, 1999, pp. 107-112. doi: $10.1007 / \mathrm{s} 001220051046$

[42] P. H. A. Sneath and R. R. Sokal, "Numerical Taxonomy, the Principle and Practice of Numerical Classification, W H Freeman and Co., San Francisco, 1973.

[43] R. R. Sokal and C. D. Michener, "A Statistical Method for the Evaluating Systematic Relationships," University of Kansas, Kansas, 1958. 
[44] L. R. Dice, "Measures of the Amount of Ecologic Association between Species," Ecology, Vol. 26, No. 3, 1945, pp. 297-302. doi:10.2307/1932409

[45] P. Jaccard, "Nouvelles Recherché sur la Distribution Florale. Bulletin," Societe Vaudoise Sciences Naturelles, Vol. 44, 1908, pp. 223-270.

[46] N. A. Mantel, "The Detection of Disease Clustering and a Generalized Regression Approach," Cancer Research, Vol. 27, No. 2, 1967, pp. 209-220.

[47] R. R. Sokal, "Ecological Parameters Inferred from Spatial Correlograms," In: G. P. Patil and M. Rosenzweig, Eds., Contemporary Quantitative Ecology and Related Econometrics, ICPH, 1979, pp. 167-196.

[48] B. D. Singh, "Plant Breeding-Principle and Metods," Kalyani Publishers, Ludhiana, 2000.

[49] C. E. Thormann and T. C. Osborn, "Use of RAPD and RFLP Markers for Germplasm Evaluation," In: Applications of RAPD Technology to Plant Breeding, Joint Plant Breeding Symposia Series, Minneapolis, 1992, pp. 9-11.

[50] A. Arif, M. A. Bakir, H. A. Khan, A. H. Al Farhan, A. A. Al Homaidan, A. H. Bahkali, et al., "Application of RAPD for Molecular Characterization of Plant Species of Medicinal Value from an Arid Environment," Genetics and Molecular Research, Vol. 9, No. 4, 2010, pp. 21912198. doi:10.4238/vol9-4gmr848

[51] W. C. Black, "Statistical Analysis of Arbitrarily Primed PCR Patterns in Molecular Taxonomic Studies," In: J. P. Clapp, Ed., Species Diagnostic Protocols: PCR and Other Nucleic Acid Methods, Humana Press Inc., Totowa, 1996, pp. 39-56.

[52] P. Joshi and V. Dhawan, "Analysis of Genetic Diversity among Swertia chirayita Genotypes," Biologia Plantarum, Vol. 51, No. 4, 2007, pp. 764-768. doi:10.1007/s10535-007-0156-Z

[53] D. Zhang, S. Chen, S. Hen, D. Zhang and Q. Gao, "Patterns of Genetic Variation in Swertia przewalskii, an Endangered Endemic Species of the Qinghai-Tibet Plateau," Biochemical Genetics, Vol. 45, No. 1-2, 2007, pp. 33-50.

[54] A. Teklewold and H. C. Becker, "Geographic Pattern of Genetic Diversity among 43 Ethiopian Mustard (Brassica carinata A. Braun) Accessions as Revealed by RAPD Analysis," Genetic Resources and Crop Evolution, Vol. 53, No. 6, 2006, pp. 1173-1185. doi:10.1007/s10722-005-2011-4

[55] W. Zheng, L. Wang, L. Meng and J. Liu, "Genetic Varia- tion in the Endangered Anisodus tanguticus (Solanaceae), an Alpine Perennial Endemic to the Qinghai-Tibetan Plateau," Genetica, Vol. 132, No. 2, 2008, pp. 123-129. doi:10.1007/s10709-007-9154-5

[56] S. Sundaram and S. Purwar, "Assessment of Genetic Diversity among Fenugreek (Trigonella foenum-graecum L.), Using RAPD Molecular Markers," Journal of Medicinal Plants Research, Vol. 5, No. 9, 2010, pp. 15431548.

[57] C. Luce, J. L. Noyer, D. Tharreau, N. Ahmadiand and H. Feyt, "The Use of Microsatellite Markers to Examine the Genetic Markers to Examine the Genetic Resources of Rice (Oryza sativa L.) Adapted to European Conditions," Acta Horticulturae, Vol. 546, 2001, pp. 221-234.

[58] V. A. Sebastian, L. D. Cruz, R. B. Subramanian and V. J. Braganza, "Assessment of Genetic Diversity within and among Populations of Tylophora rotundifolia Using RAPD Markers," Gene Conserve, Vol. 9, No. 37, 2010, pp. 94-117.

[59] J. C. Rief, A. E. Melchinger and M. Frisch, "Genetical and Mathematical Properties of Similarity and Dissimilarity Coefficients Applied in Plant Breeding and Seed Bank Management," Crop Science, Vol. 45, No. 1, 2005, pp. 1-7. doi:10.2135/cropsci2005.0001

[60] M. Nei and W. H. Li, "Mathematical Model for Studying Genetic Variation in Terms of Restriction Endonucleases," Proceedings of the National Academy of Sciences of the United States of America, Vol. 76, No. 10, 1979, pp. 5269-5273.doi:10.1073/pnas.76.10.5269

[61] K. V. Bhat, P. B. Prashant and S. Lakhanpaul, "Study of Genetic Diversity in Indian and Exotics Sesame (Sesamum indicum L.) Germplasm Using Random Amplified Polymorphic DNA (RAPD) Markers," Euphytica, Vol. 110, No. 1, 1999, pp. 21-33. doi:10.1023/A:1003724732323

[62] S. P. J. Prakash, K. R. Biji, S. M. Gomez, K. G. Murthy and R. C. Babu, "Genetic Diversity Analysis of Sorghum (Sorghum bicolor L. Moench) Accessions Using RAPD Markers," Indian Journal of Crop Science, Vol. 1, No. 1-2, 2006, pp. 109-112.

[63] M. Slatkin, "Gene Flow and Geographic Structure of Natural Populations," Science, Vol. 236, No. 4803, 1987, pp. 787-792. doi:10.1126/science. 3576198

[64] D. Tilman, "Causes, Consequences and Ethics of Biodiversity," Nature, Vol. 405, 2000, pp. 208-211. doi: $10.1038 / 35012217$ 